\title{
CENTRAL STATE CHILD CARE POLICIES IN POSTAUTHORITARIAN SPAIN Implications for Gender and Carework Arrangements
}

\author{
CELIA VALIENTE \\ Universidad Carlos III de Madrid
}

In Spain, public preschool programs have continuously expanded in the past three decades. However, this education policy has done little to support increases in the proportion of women in the paid workforce. Preschool is not child care because the former does not address the care needed by children younger than three years old and offers programs with short hours and long holidays.

Keywords: child care; preschool; women's movement; gender; Spain

Child care can be thought of as a labor market, gender equality, or education policy. I argue that in postauthoritarian Spain, the educational rationale has been the predominant one, and it has succeeded in expanding the supply of places in free public preschools. Nevertheless, the very definition of these institutions as schools rather than child care centers has limited their utility for working mothers. Preschool programs provide solid educational services for children three to five years old. Addressing the educational needs of young children (from all social classes) is a laudable goal, and its achievement should be celebrated. However, preschool programs ignore care required by infants and toddlers as well as the child care needed by mothers to ensure employment access. ${ }^{1}$

\footnotetext{
AUTHOR'S NOTE: I would like to thank the journal's anonymous reviewers for their valuable comments and suggestions.

REPRINT REQUESTS: Celia Valiente, Department of Political Science and Sociology, Universidad Carlos III de Madrid, Calle Madrid 126, 28903 Getafe, Madrid, Spain; e-mail: valiente@ polsoc.uc3m.es.
} 


\section{CHILD CARE AS EDUCATION POLICY}

In many advanced industrial societies, social provisions like child care have been reduced or eliminated in the recent trend toward welfare state retrenchment (Clayton and Pontusson 1998; Garrett 1998; Pierson 1998; Stephens, Huber, and Ray 1999). However, in Spain, public provision of central state child care has increased steadily since the end of the right-wing authoritarian regime in 1975. Since 1975, conditions in Spain have been less favorable toward child care policy rationales other than the educational approach. Child care provisions have often been expanded in other countries during periods of labor shortage to facilitate the employment of women with children-the most important available reserve of labor. In Spain, however, there have been no such labor force shortages for the past three decades. Indeed, the unemployment rate hovered above 13 percent between 1981 and 2001, and it is unlikely that labor shortages will develop in the foreseeable future. $^{2}$

At the same time, after 1975, the political and social actors who might have defined child care measures as programs that benefit working mothers and provide gender equality (such as feminists within the women's movement, gender equality institutions, political parties, and trade unions) have not consistently advanced this definition in practice for two reasons. First, in postauthoritarian Spain, feminists have been overwhelmed by the amount of other demands that they have had to advance and that had already been achieved in other Western countries, among them the equality of women and men before the law, the decriminalization of the sale and advertising of contraceptives (achieved in 1978) or abortion under some circumstances (accomplished in 1985), the establishment of divorce (obtained in 1981), and the criminalization of violence against women. Second, between the late 1930s and 1975, the existence of a right-wing authoritarian regime contributed to moving Spanish feminists away from issues such as motherhood and child care later on. The official doctrine of the dictatorship defined motherhood as women's main duty toward the state and society and affirmed that the role of mothering was incompatible with others, such as that of waged worker (Nash 1991, 160). After almost 40 years of being literally bombarded with the idea of mothering and caring as the most important task in women's lives, the last thing Spanish feminists wanted to do after the dictatorship was to pay a lot of attention to the issues of motherhood and child rearing. Women's liberation was then understood as opening the range of concerns that define women's lives, such as waged work, political participation, or control of their bodies. This definition carefully eludes the place of motherhood and child care in the life of the newly liberated female Spaniards. ${ }^{3}$

Instead, policy makers active in the area of child care (mainly from the Ministry of Education) have relied primarily on the educational logic, focusing on measures explicitly intended to benefit children. Since 1975, the main central state child care policy has been to supply an ever increasing number of free educational preschool programs for children between the ages of three and five (mandatory schooling starts at six) ${ }^{4}$ As a result of this policy, in the academic year 2001-2002, school 
attendance rates for three-, four-, and five-year-olds were comparatively high in Spain at 98 percent. ${ }^{5}$ In contrast, the proportion of Spanish children aged two or younger cared for in public or private centers is one of the lowest in the European Union: 1.3 percent for children younger than one year, 5.7 percent for children aged one year, and 13.7 percent for those two years old (Ministerio de Educación y Cultura 2001, 69, 122-23; my calculations). ${ }^{6}$

\section{ORIGINS OF THE EDUCATION RATIONALE}

In Spain, child care has always been an education policy independent of the different types of political regimes that governed the country during the twentieth century. Since the dictatorship, the supply of places in free public preschools has been expanded by parties of different ideological colors while they have held office (although for different reasons): a Center-Right coalition of parties up to 1982, a Social-Democratic party between 1982 and 1996, and a Conservative party since then. These three governments have understood the increasing access of children to preschool services as a necessary step for Spain to catch up with surrounding countries since most European Union member states are economically more developed. All three governing groups have thought that one of the reasons for the relative backwardness of Spain was an education deficit. Since 1975, there has been a constant rise in expenditures within all levels of education, not just preschool (Uriel et al. 1997). The Social-Democratic party promoted public preschool to diminish class inequality because, historically, access to nonmandatory education was sharply differentiated by class. The Conservative party, in power since 1996, has maintained and increased the supply of publicly supported preschool. In the context of strong electoral competition from the Social-Democratic party, the Conservatives do not want to be seen by the electorate as a party that defends the interests of affluent citizens who tend to use private child care and preschool programs.

\section{CHILD CARE POLICIES AND THE GENDERED LABOR FORCE}

Public preschool programs cannot be used by mothers as perfect substitutes for child care, since preschool hours are shorter than the work hours for full-time jobs (and sometimes much shorter and interrupted by a break). It is necessary to stress that even if women's employment rate (34 percent in the first quarter of 2002) is comparatively very low, most Spanish women who work for wages ( 83 percent in the last quarter of 2001) have full-time jobs (Instituto Nacional de Estadística 2002). Preschool holidays (usually three months) are much longer than paid work holidays (one month).

The acute scarcity of child care for children aged two or younger and the fact that available child care is preschool education for children between the ages of three 
and five helps explain the comparatively low Spanish female employment rate. Other reasons include the general scarcity of employment in Spain for both men and women (men's employment rate was also unusually low at 61 percent in the first quarter of 2002) (Instituto Nacional de Estadística 2002), the lack of incentives provided by authorities to create part-time work up until the 1990s, gender discrimination in hiring, and the shortage of care services for other people in need such as the frail elderly, the sick, and the handicapped. Because of its limitations, child care policy in Spain has not significantly contributed to reversing the historical pattern of low levels of women's participation in the labor market. In 1976, the female employment rate was 27 percent, and since then, it has fluctuated to reach the current 34 percent (Instituto Nacional de Estadística 2002).

In this context, it is not surprising that some Spanish mothers of working age conceptualize the combination of work and family responsibilities as an impossible mission and do not even try. Other mothers try it by using not only preschool services but also help from female relatives (usually grandmothers) and to a lesser extent from the children's fathers and, for the middle-class, paid carework from domestic servants (Tobío 1999). Therefore, the transformation of child care policy into a useful resource for women to participate in the Spanish labor market is a policy goal still pending achievement in the future.

\section{CONCLUSION}

In Spain, the public provision of child care has increased steadily in the past quarter of a century. However, because this provision has relied on an education rationale, the existing centers cannot provide child care for employed mothers since they operate like preschools with short hours, frequent holidays, and long summer breaks. In other countries, preschool programs are now being developed at the expense of care-based programs for infants and toddlers. The Spanish case shows that while the expansion of preschool is positive, it has limited benefit as comprehensive child care.

\section{NOTES}

1. This report draws heavily on Valiente $(2001,2002)$.

2. The unemployment rate is the proportion of registered unemployment in the active population (which is the employed and the registered unemployed).

3. For more in English on the Spanish women's movement and Spanish feminist approaches to public policies (including child care), see Durán and Gallego (1986), Kaplan (1992, 191-210), and Threlfall (1985, 1996).

4. While preschool programs in public centers enrolled 347,026 children younger than six in the academic year 1975-1976, by 2001-2002, this figure had more than doubled (798,565 children; provisional data for 2001-2002) (Instituto Nacional de Estadística 1977, 101; Ministerio de Educación y Cultura 2002). 
5. Approximately two-thirds of children aged three, four, and five years old are now enrolled in public preschools, while the remaining third is enrolled in private preschools (Ministerio de Educación y Cultura 2002).

6. In social science research, Spain is often compared with other European Union member states, even in studies like this on issues such as child care, for which no mandatory European Union regulation exists.

\section{REFERENCES}

Clayton, Richard, and Jonas Pontusson. 1998. Welfare-state retrenchment revisited: Entitlement cuts, public sector restructuring and inegalitarian trends in advanced capitalist societies. World Politics 51:67-98.

Durán, María A., and María T. Gallego. 1986. The women's movement in Spain and the new Spanish democracy. In The new women's movement: Feminism and political power in Europe and the USA, edited by Drude Dahlerup. London: Sage.

Garrett, Geoffrey. 1998. Partisan politics in the global economy. New York: Cambridge University Press.

Instituto Nacional de Estadística. 1977. Estadística de la enseñanza en España: Curso 1975-76 (Statistics on education in Spain: Academic year 1975-76). Madrid, Spain: National Institute of Statistics.

2002. Encuesta de población activa (Active population survey). Madrid, Spain: National Institute of Statistics. Available from http://www.ine.es.

Kaplan, Gisela. 1992. Contemporary Western European feminism. London: UCL Press and Allen \& Unwin.

Ministerio de Educación y Cultura. 2001. Estadísticas de la educación en España 1998-1999: Resultados detallados, series e indicadores (Statistics on education in Spain 1998-1999: Detailed results, series and indicators). Madrid, Spain: Ministry of Education and Culture.

__ 2002. Estadisticas de las enseñanzas no universitarias: Series e indicadores $1992-93$ a 200102 (Statistics on nonuniversity education in Spain: Series and indicators 1992-93 to 2001-02). Madrid, Spain: Ministry of Education and Culture. Available from http://www.mec.es.

Nash, Mary. 1991. Pronatalism and motherhood in Franco's Spain. In Maternity and gender politics: Women and the rise of European welfare states, 1880 s-1950s, edited by Gisela Bock and Pat Thane. London: Routledge.

Pierson, Paul. 1998. Irresistible forces, immovable objects: Post-industrial welfare states confront permanent austerity. Journal of European Public Policy 5 (4): 539-60.

Stephens, John D., Evelyne Huber, and Leonard Ray. 1999. The welfare state in hard times. In Continuity and change in contemporary capitalism, edited by Herbert Kitschelt, Peter Lange, Gary Marks, and John D. Stephens. New York: Cambridge University Press.

Threlfall, Monica. 1985. The women's movement in Spain. New Left Review 151:44-73.

- 1996. Feminist politics and social change in Spain. In Mapping the women's movement: Feminist politics and social transformation in the North, edited by Monica Threlfall. London: Verso.

Tobío, Constanza. 1999. Solidaridad y cambio entre generaciones de mujeres (Solidarity and change among generations of women). In Género y ciudadanía (Gender and citizenship), edited by Margarita Ortega, Cristina Sánchez, and Celia Valiente. Madrid, Spain: Autonomous University of Madrid.

Uriel, Ezequiel, María L. Moltó, Francisco Pérez, Joaquín Aldás, and Vicent Cucarella. 1997. Las cuentas de la educación en España y sus Comunidades Autónomas: 1980-1992 (Education accounts in Spain and its regions: 1980-1992). Madrid, Spain: Argentaria Foundation and Visor.

Valiente, Celia. 2001. Do political parties matter? Do Spanish parties make a difference in child care policies? In Promoting evidence-based practice in early childhood education: Research and its implications, edited by Tricia David. Amsterdam: JAI. 
2002. The value of an educational emphasis: Child care and restructuring in Spain since 1975. In Child care policy at the crossroads: Gender and welfare restructuring, edited by Sonya Michel and Rianne Mahon. New York: Routledge.

Celia Valiente is a visiting professor (profesora visitante) in the Department of Political Science and Sociology at the Universidad Carlos III de Madrid, Spain. Her research deals with public policies and social movements with the perspective of gender. 